Out of hours investigations are no longer used exclusively for diagnosis leading to urgent treatment. Deleting tests that do not meet traditional criteria of urgency might thus lead to additional costs-for example, by delaying discharge of a patient at the weekend or necessitating earlier admission so that preoperative tests could be done during normal working hours.

Although the need to reduce costs is obvious, the reductions must be both financially worthwhile and not affect patient care. Reducing laboratory work done out of hours probably does not meet these criteria. The cost and effectiveness of laboratory investigations need to be improved by day as well as by night, using a strategy that will influence the requesting practices of doctors. ${ }^{11}$ Reducing laboratory costs should not be the primary motivation for doing this.

P M G BROUGHTON

Deputy Director,

Wolfson Research Laboratories,

Department of Clinical Chemistry,

Queen Elizabeth Medical Centre,

Birmingham B15 2TH

1 Sandler G. Costs of unnecessary tests. Br Med f 1979;ii:21-4.

2 Sandler G. Do emergency tests help in the management of acute medical admissions? $\mathrm{Br} \mathrm{Med} \mathcal{F}$ 1984;289:973-7.

3 Broughton PMG, Woodford FP. Benefits of costing in the clinical laboratory. $f$ Clin Pathol 1983;36:1028-35.

4 Winkel P, Statland BE. Assessing cost savings when unnecessary utilisation of laboratory tests can inkel P, Statland BE. Assessing cost savings when
be abolished. Am $\mathcal{F}$ Clin Pathol 1984;82:418-23.

5 Winkelman JW. Less utilisation of the clinical laboratory produces disproportionally small true cost reductions. Hum Pathol 1984;15:499-501.

6 Gray TA, McLeod AJ, Bignell AHC. Future of the pathologist in an era of technological change and cost containment. BrMed F 1987;294:902-3.

Gunn IR, Little AJ, Payne RB. Effects of workload and analysis time on the cost of out-of-hours investigations. Ann Clin Biochem 1986;23:502-3.

8 Smith ADS, Shenkin A, Dryburgh FJ, Morgan HG. Emergency biochemistry services-are they abused? Ann Clin Biochem 1982;19:325-8.

9 Lester E. A new strategy for out-of-hours laboratory investigations. Ann Clin Biochem 1986;23:497-500.

10 Payne RB, Young RM. Out-of-hours chemical pathology. Lancet 1985;ii: 103.

11 Fraser GC, Woodford FP. Strategies to modify the test-requesting patterns of clinicians. Ann Clin Biochem 1987;24:223-31.

\section{Use and abuse of allopurinol}

Allopurinol was first synthesised as an adjunct to anticancer treatment with mercaptopurine in 1960 but was found to have powerful hypouricaemic effects. ${ }^{1}$ It has caused severe tophaceous gout to all but vanish, and renal complications of gout are now rare. ${ }^{2}$ Recently a controlled trial has confirmed that allopurinol can inhibit the formation of calcium oxalate stones in the $15-20 \%$ of patients who form stones and who are hyperuricosuric. ${ }^{3}$ More than 5 million patient years of treatment have now accumulated, and more than 70 tonnes of what is in general a safe and effective agent are ingested each year. Minor reactions to the drug do occur-probably $2 \%$ of patients will develop itching and rashes. ${ }^{4}$ More severe reactions, including exfoliative dermatitis or toxic epidermolysis, eosinophilia with interstitial nephritis or vasculitis, hepatic granulomas, and bone marrow depression have been described in about 350 patients, ${ }^{5-23}$ with a further 250 unpublished cases (G Lovett, personal communication). Many of those suffering severe reactions had reduced renal function and often the dose of allopurinol used was either not stated or was too high for the degree of renal function. ${ }^{7-22}$ We believe that these toxic effects could mostly have been avoided by better understanding of the metabolism and renal handling of the drug.

About $60-70 \%$ of allolpurinol is metabolised to its active principle, oxipurinol, which is excreted through the kidney together with allopurinol itself and allopurinol riboside, the second main metabolite. ${ }^{24}$ Unlike allopurinol and its riboside, which are rapidly cleared, oxipurinol undergoes net reabsorption in the renal tubule, ${ }^{2526}$ just like urate itself. Oxipurinol may thus accumulate easily in patients with renal failure, in patients with gout or in patients being treated with thiazides because their fractional excretion of urate and oxipurinol is low. A single dose of allopurinol may achieve therapeutic concentrations of oxipurinol $(40-60 \mu \mathrm{mol} / \mathrm{l})$ in the plasma for a week or longer; ${ }^{232526}$ we have found plasma oxipurinol concentrations as high as $300 \mu \mathrm{mol} / \mathrm{l}{ }^{23}$ In addition, as with urate transport, the net reabsorption of oxipurinol is greatly increased in states of volume contraction and hypovolaemia. ${ }^{27}$ including those induced by diuretics; net reabsorption is decreased in states of volume expansion. Clearance of oxipurinol is also altered by changes in the glomerular filtration rate, ${ }^{624}$ including the transient changes induced by differences in protein ingestion. ${ }^{28}$

Suggested maintenance dose of allopurinol for patients with diminished renal function

\begin{tabular}{cl}
\hline Creatinine clearance $(\mathrm{ml} / \mathrm{min})$ & Allopurinol dose \\
\hline 0 & $100 \mathrm{mg}$ thrice weekly \\
10 & $100 \mathrm{mg}$ on alternate days \\
20 & $100 \mathrm{mg}$ daily \\
40 & $150 \mathrm{mg}$ daily \\
60 & $200 \mathrm{mg}$ daily \\
$\geqslant 100$ & $300 \mathrm{mg}$ daily \\
\hline
\end{tabular}

Despite the fact that this information has long been available many patients with renal impairment are still given too high a dose of allopurinol. Most of these treated with the drug are middle aged and elderly, and even in those without cardiac or renal disease renal function diminishes steadily with age, although plasma creatinine or urea concentrations do not rise to signal this decline. ${ }^{29}$ Plasma oxipurinol assays are not readily available, and our own and other workers' data lead to the suggestions shown in the table for maintenance doses of allopurinol in patients with diminished renal function. ${ }^{23263031}$ If only the plasma creatinine concentration is available then a formula that takes account of age as well as body size (based on that of Cockroft and Gault ${ }^{32}$ ) may be used to calculate the clearance:

creatinine clearance $(\mathrm{ml} / \mathrm{min})=\frac{140-\text { age in years } \times \text { weight in kilograms }}{7.6 \times \text { plasma creatinine concentration in } \mu \mathrm{mol} / 1}$

If the urate clearance is known to be reduced the dose should be reduced even further. In patients with normal renal function the dose should not exceed $300 \mathrm{mg} / 24 \mathrm{~h}$ initially and rarely needs to exceed it thereafter except in the unusual case of resistance to the drug. ${ }^{33}$ Side effects can usually be prevented, even on rechallenge, by starting the dose at $5-10 \mathrm{mg} / 24 \mathrm{~h}$ and then increasing it gradually. ${ }^{6}$

A further problem arises when allopurinol is used to redistribute the excreted purine load away from just urate in patients with gross purine overproduction-that is, those being treated for malignancies of the bone marrow or lymphomas ${ }^{234}$ and those with inherited deficiencies of the enzyme hypoxanthine-guanine phosphoribosy/transferase. ${ }^{34} 35$ Complete deficiency of this enzyme leads to the Lesch-Nyhan syndrome and incomplete deficiency to sex linked familial gout. During treatment with allopurinol the purine end products are a much reduced amount of urate, 
accompanied by a considerable increase in the excretion of xanthine, and a lesser amount of hypoxanthine. ${ }^{2334}$ Hypoxanthine is soluble, but xanthine is about as insoluble as urate-but, unlike urate, its solubility does not increase when the urine is alkalinised. Thus when allopurinol is used in states of gross urate overproduction xanthine may precipitate in the kidney and urinary tract. ${ }^{23} 35.44$

Allopurinol must thus be used with care and given only when there is clear evidence of therapeutic benefit. Its use in gout is established, and as well as controlling symptoms it may protect renal function, ${ }^{45}$ especially in familial cases ${ }^{46}$ Its use for moderate symptomless hyperuricaemia has so far no firm support ${ }^{612}$ either for protecting renal function ${ }^{47}$ or reducing cardiovascular risk. Because of the very occasional disastrous reaction the use of allopurinol is not recommended in the many people with mild symptomless hyperuricaemia. In any patient presenting with gout or hyperuricaemia potential causes such as diet and drugs, particularly diuretics, should be sought and eliminated. In men under 30 and women not taking diuretics specialist advice should be sought to exclude metabolic defects before beginning treatment with allopurinol.

J STEWART CAMERON Professor of renal medicine

\section{H ANNE SimMONDS}

Director,

Purine Laboratory

United Medical and Dental Schools of

Guy's and St Thomas' Hospitals (Guy's Campus)

London SE1 9RT

Rundles RW. The development of allopurinol. Arch Intern Med 1985;145:1492-503.

Beck LH. Requiem for gouty nephropathy. Kidney Int 1986;30:280-7.

Ettinger B, Tang A, Citron JT, Livermore B, Williams T. Randomized trial of allopurinol in the prevention of calcium oxalate calculi. $N$ Engl $\mathcal{F}$ Med 1986;315:1386-9.

prever 1 , Lawson DH, Jick $H$. Acute adverse reactions atributed to Dis 1981;40:245-9.

5 Hande KR, Noone RM, Stone WJ. Severe allopurinol toxicity. Description and guidelines for prevention in patients with renal insufficiency. $A m \mathcal{F} M$ Med 1984;76:47-56.

6 Singer JZ, Wallace SL. The allopurinol hypersensitivity syndrome. Unnecessary morbidity and mortality. Arthritis Rheum 1986;29:82-7.

Dan $M$, Jedwab $M$, Peed $M$, Shibolet S. Allopurinol-induced toxic epidermal necrolysis. Int $\mathcal{J}$ Dermatol 1984;23:142-4.

8 Fong PH, Ratnagopal P, Wong KL. Drug induced toxic epidermal necrolysis. Singapore Med $\mathcal{J}$ 1984;25:184-6.

9 Rader R, Barnes P, Ibels L, Lunzer M, Lauer C. Fuliminant hepatic failure due to allopurinol. Aust NZ F Med 1984;14:63-5.

10 Mousson C, Justrabo E, Tantez Y, Chalopin JM, Rifle G. Hépatite et néphrite interstitielle aigues granulomateuses d'origine médicamenteuse. Néphrologie 1984;5:94-5.

11 Pennell DJ, Nunan PO, O'Doherty MJ, Croft DN. Fatal Stevens-Johnson syndrome in a patient on captopril and allopurinol. Lancet 1984; i:453.

12 Aubock J, Fritsch P. Asymptomatic hyperuricaemia and allopurinol indiced toxic epidermal necrolysis. BrMed f 1985;290:1969-70.

13 Webster E, Panush RS. Allopurinol hypersensitivity in a patient with severe, chronic, tophaceous gout. Arhhritis Rheum 1985;28:707-9.

14 Stein CM. Allopurinol hypersensitivity. S Afr Med f 1985;67:935-6.

15 Renwick IGH. Asymptomatic hyperuricaemia and allopurinol induced toxic epidermal necrolysis. BrMed $\mathcal{~} 1985 ; 291: 485$.

16 Worth CT, Hussein SM. Peripheral neuropathy due to long-term ingestion of allopurinol. $\mathrm{Br}$ Med f 1985;291:1688.

17 Ebel V, Baumann R, Czechanowski R, et al. Funf Fälle mit medikamenter- induzierten Lyellsyndrom. Innere Medizin 1985;12:280-4.

18 Vanderstigel M, Zafrani ES, Lejonc JL, Schaeffer A, Portos JL. Allopurinol hypersensitivity syndrome as a cause of hepatic fibrin ring granulomas. Gastroenterology 1986;90:188-90.

19 Guerin C, Genin C, Toulon J, Sabatier JC, Leroy G, Berthoux F. Toxicité severe de l'allopurinol. Néphrologie 1986;7:47-9.

20 Conrad ME. Fatal aplastic anemia associated with allopurinol therapy. Am $\mathcal{f}$ Hematol 1986;22: 107-8.

21 Wagner P, Sweet J, Bear RA. Granulomatous interstitial nephritis associated with allopurinol therapy. Can Med Ass J 1986;135:496-7.

22 Ohsawa T, Ohtsubo M. Hepatitis associated with allopurinol. Drug Intell Clin Pharm 1986;19: 431-3.

23 Simmonds HA, Cameron JS, Morris GS, Davies PM. Allopurinol in renal failure and the tumour lysis syndrome. Clin Chim Acta 1986;160:189-95.

24 Reiter S, Simmonds HA, Webster DR, Watson AR. On the metabolism of allopurinol. Formation of allopurinol-1-riboside in purine nucleoside phosphorylase deficiency. Biochem Pharmacol 1983;32:2167-74.

25 Hande K, Reed E, Chabner B. Allopurinol kinetics. Clin Pharmacol Ther 1978;23:598-605.

26 Elion GB, Yu T-F, Gutman AB, Hitchings GH. Renal clearance of oxipurinol, the chief Elion GB, Yu T-F, Gutman AB, Hitchings GH. Rent
metabolite of allopurinol. Am $\mathcal{J}$ Med 1968;45:69-77.

27 Wood MH, Sebel E, O'Sullivan WJ. Allopurinol and thiazides. Lancet 1972;i:751.

28 Berlinger WG, Park GD, Spector R. The effect of dietary protein on the clearance of allopurinol and oxypurinol. $N$ Engl I Med 1985;313:771-6.

29 Macias JF, Cameron JS. Renal function and renal disease in the elderly. London: Butterworths, 1987.

30 Elion GB, Benezra FM, Beardmore TD, Kelley WN. Studies with allopurinol in patients with impaired renal function. Adv Exp Med Biol 1980;122A:263-7.
31 Hayes CP, Metz EN, Robinson RR, Rundles RW. Use of allopurinol (HPP) to control hyperuricemia in patients on chronic intermittent dialysis. Trans Am Soc Artif Intern Organs 1965;11:247-51

32 Cockcroft D, Gault MK. Prediction of creatinine clearance from serum creatinine. Nephron 1976;16:31-41.

33 Gibson T, Simmonds HA, Rodgers AV, et al. Gout with apparent resistance to allopurinol. Ann Rheum Dis 1983;42:93-5.

34 Hande KR, Hixson CV, Chabner BA. Postchemistry purine excretion in lymphoma patients receiving allopurinol. Cancer Res 1981;41:2273-9.

35 Greene ML, Fujimoto WY, Seegmiller JM. Urinary xanthine stone. A rare complication of allopurinol therapy. N Engl I Med 1969;280:426-7.

36 Band PR, Silverberg DS, Henderson Jf, et al. Xanthine nephropathy in a patient with lymphosarcoma treated with allopurinol. $N$ Engl f Med 1970;283:354-7.

37 Mizuno T, Segawa M, Kurumada T, et al. Clinical and theraputic aspects of the Lesch-Nyhan syndrome in Japanese children. Neuropadiatrie 1970;2:38-52.

38 Manzke H, Harms D, Dorner K. Zur Problematik der Behandlung der kongenitalen Hyperurikämie. Monatschrift für Kinderheilkunde 1971;119:424-8.

39 Ablin A, Stephens BG, Nirata T, et al. Nephropathy, xanthinuria and orotic aciduria complicating Burkitt's lymphoma treated with chemotherapy and allopurinol. Metabolism 1972;21:771-8.

40 Gomez GA, Stutzman L, Chu TM. Xanthine nephropathy during chemotherapy in deficiency of hypoxanthine-guanine phosphoribosyltransferase. Arch Intern Med 1978;138:1017-9.

41 Sperling O, Brosh S, Boer P, et al. Urinary xanthine stones in an allopurinol-treated gouty patient with partial deficiency of hypoxanthine-guanine phosphoribosyltransferase. Isr $7 \mathrm{Med} S \mathrm{Si}$ 1978;14:288-92.

42 Brock WA, Golden J, Kaplan GW. Xanthine calculi in the Lesch-Nyhan syndrome. $\mathcal{J}$ Urol 1983;130:157-9.

43 Ogawa A, Watanabe K, Minejima N. Renal xanthine stone in Lesch-Nyhan syndrome treated with allopurinol. Urology 1985;26:56-8.

44 Oka T, Utsonomiya M, Ichikawa $Y$, et al. Xanthine calculi in the patient with the Lesch-Nyhan syndrome associated with urinary tract infection. Urol Int 1985;40:138-40.

45 Gibson T, Highton J, Potter C, Simmonds HA. Renal impairment and gout. Ann Rheum Dis 1980;39:417-23.

46 Simmonds HA, Warren DJ, Cameron JS, Potter CF, Farebrother DA. Familial gout and renal failure in young women. Clin Nephrol 1980;14:176-82.

47 Rosenfeld JB. Effect of long-term allopurinol administration on serum creatinine and GFR in normotensive and hypertensive hyperuricemia subjects. Adv Exp Biol Med 1974;41B:581-96.

\section{Vasomotor rhinitis}

Vasomotor rhinitis remains a diagnosis of exclusion, and the alternative term non-allergic non-infective rhinitis describes the condition better. Vasomotor rhinitis accounts for between one and two thirds of cases of chronic perennial rhinitis ${ }^{12}$ and is less common in children and more common in the elderly. ${ }^{3}$ As with allergic rhinitis, vasomotor rhinitis produces nasal obstruction and watery rhinorrhoea, but, in contrast, nasal itching and sneezing are less common. ${ }^{4}$ Recently vasomotor rhinitis has been subdivided into eosinophilic and non-eosinophilic forms on the basis of the proportion of eosinophils in nasal secretion smears ${ }^{2}$ Eosinophilic vasomotor rhinitis is characterised by appreciable nasal obstruction, moderate rhinorrhoea, and anosmia, whereas the noneosinophilic form is associated with profuse rhinorrhoea but only mild to moderate nasal obstruction. ${ }^{4}$ This pathological division fits with earlier clinical observations of two syndromes, ${ }^{5}$ and non-eosinophilic vasomotor rhinitis is almost twice as common as the eosinophilic form. ${ }^{2}$

The classical theory is that vasomotor rhinitis is caused by autonomic imbalance ${ }^{6}$ : underactivity of the sympathetic nervous system leading to nasal obstruction; and overactivity of the parasympathetic nervous system leading to rhinorrhoea. ${ }^{5}$ This theory is probably true for noneosinophilic vasomotor rhinitis. ${ }^{7}$ Interruption of the sympathetic nerve supply to the nose causes nasal obstruction, ${ }^{8}$ and electrical stimulation causes nasal decongestion. ${ }^{9}$ Giving $\alpha$ receptor agonists experimentally also causes nasal decongestion. ${ }^{10}$ Patients treated with the $\alpha$ receptor antagonist methyldopa may develop nasal obstruction, ${ }^{511}$ and treatment with non-selective $\beta$ antagonists may produce watery rhinorrhoea. ${ }^{12}$ Electrical stimulation of the nasal parasympathetic nerve supply of the dog causes nasal obstruction ${ }^{13}$ and watery rhinorrhoea ${ }^{14}$ Interruption of the parasympathetic nerve supply in patients with vasomotor rhinitis may control rhinorrhoea and sneezing at least in the short term. ${ }^{15}$ 